\title{
BETWEEN FACT AND FICTION IN DAN BROWN'S THE DA VINCI CODE (2003): READER RESPONSE ANALYSIS
}

\author{
Wahyu Unggul Widodo \\ STIKES An Nur Purwodadi, Jawa Tengah, Indonesia \\ E-mail : wahyuunggulwidodo@gmail.com
}

\begin{abstract}
Submit: 13-08-2018 Review: 30-08-2018 Accepted: 30-08-2018
\end{abstract}
Doi: $10.22202 /$ tus.2018.v4i2.2796

\begin{abstract}
The research's purpose is to analyze reader response strategies which are used by readers to respond Dan Brown's the Da Vinci Code novel. The objectives of the study are to know kind of reader response strategies that are applied by the readers to respond Dan Brown's the Da Vinci Code, to describe how the readers apply the reader response strategies on Dan Brown's the Da Vinci Code, to describe the dominant issues raised by the readers in applying reader response strategy on Dan Brown's the Da Vinci Code and to know why the issues are problematic. This study is a qualitative study; the primary data source of the study is the responses from amazon customers and the guest who drop responds to the Da Vinci Code novel in amazon.com. The responses which are taken are from the paperback version and it is limited to the responses which were dropped on June $10^{\text {th }} 2006$ until February $7^{\text {th }} 2015$ and the secondary data sources of the study are books, journals or any information related to reader response strategy. In analyzing the data, the writer employs descriptive analysis. The outcome of the study shows the readers use various reader response strategies to respond Dan Brown's the Da Vinci Code. The readers apply the strategies in responding by describing character, plot, setting, style and theme and judging the content of the novel, storyline, the author and the writing (textual reader-response strategy), explaining what the characters do and interpreting their opinion about story or part of the story in the novel (Psychological reader-response strategy), connecting the novel with their personal experience or other stories they have read and engaging with a story when they are articulating their personal emotional reaction or level of involvement with the story (Experiential readerresponse strategy), connecting the story or part of it to a religion value (cultural readerresponse strategy) and connecting the story or part of it to a social life value or something related to it (Social reader-response strategy).The dominant issue which is raised by the reader is a debatable problem in the novel dealing with the fact and fiction, there is a great possibility it becomes a problematic because Brown's initial statement in the beginning of the novel, "All descriptions of artwork, architecture, documents, and secret rituals in this novel are accurate."
\end{abstract}

Keywords: Reader Response Strategies, Richard Beach, The Da Vinci Code 


\section{INTRODUCTION}

Study on reader response analysis may have been conducted by researchers in some different ways. This study is interesting to be discussed, because by analyzing various responses from readers the researchers will get various interpretations about certain text. Some of the studies on reader response are as follows;

First study is conducted by Jeremiah Adam Shelton, with the title $A$ Comparative Reader-Response Analysis Between The Stranger And Crime And Punishment (2011). Jeremiah examined and contrasted the work of Albert Camus' The Stranger with Fyodor Dostoevsky's Crime and Punishment, from a reader response perspective as an inmate serving a 38-year sentence in the Illinois Department of Corrections. Jeremiah concluded that Camus did not allow Meursault, the main character, to explore the limits of the idea of the absurd man. In contrast, Dostoevsky was able to create a genuine consciousness in Raskolnikov, not only by Raskolnikov's realistic portrayal but by leaving Raskolnikov's ideas incomplete which the reader carried with him or herself long after the novel was finished.

Second study is Allegory or Parody? Interpretation of the Libro de buenamor's “trobacazurra” Lyric and Reader-Response and Reception Theory (2008) by Kenneth Max Gorfkle. This study applies reader-response and reception theory to the "trobacazurra" lyric of the Juan Ruiz'sLibro de buenamor. Kenneth emphasized the analysis on the response of four types of audiences, the medieval clergy, the nobility, the lay audience and the modern audience. The responses from those audiences, then classified into allegory or parody.

Third study is conducted by Vincent Piturro, The Audience and the Film: A Reader-Response Analysis of Italian Neorealism (2008). This study uses a reader-response/reception study framework to analyze Italian Neorealism. The 
central question of the study is practical: How did viewers construct meaning from their interaction with the films? Vincent argues that the interaction of the viewer with Neorealism reveals the body of films as an ultimately conservative humanistic movement that apologizes for Fascism, finds new villains for Italian society to oppose, and, ultimately, calls for a new, unified Italy.

Fourth study is The Application Of Connecting Strategy In Appreciating Brown's Film The Da Vinci Code By The Fourth Semester Students Of English Study Program Faculty Of Teacher Training And Education University Of PGRI Palembang (2009) by Muhammad Fajri. In this study, Fajri focusses on the application of connecting strategy in appreciating Brown's film The Da Vinci Code and how is the appreciation made by the students. The population of this study was the fourth semester students of English Study Program Faculty of Teacher's Training and Education University of PGRI Palembang in academic year 2007/2008. From the result of questionnaire analysis, the students were interested in appreciating literary works by using connecting strategy. The students did not face difficulties in connecting the film to other books, and connecting the film with their life experience, social life, culture and religion.

Fifth study is conducted by Heidi Kay Hammond with the title Graphic Novels and Multimodal Literacy: A Reader Response Study (2009). This study is to determine how students make meaning of and responds to a graphic novel, 23 twelfth grade students in a political science class read American Born Chinese twice. This study employed qualitative methods based on reader-response theory. Types of data collected included oral and written responses of students, student reading questionnaires, teacher and student interviews, observations as recorded in researcher field notes, and student created comics Evidence from this study supports the benefits of teaching comics' conventions and reading graphic novels as part of the curriculum to improve multimodal literacy skills. 
In this paper the writer wants to explain more about the application of reader response strategy on Dan Brown's the Da Vinci Code. What kinds of strategies are applied by the readers and how they applied them?

\section{THEORETICAL FOUNDATION}

Reader-response strategies can be categorized, according to Richard Beach in A Teacher's Introduction to Reader-Response Theories (1993), into five types: textual, experiential, psychological, social, and cultural. Textual Reader-Response Strategy in which the responses are driven by text itself. The reader and text interact in the process of formulating a meaning of the text. The scholars are drawing on the role of the reader/viewer, because they were interested in how readers' knowledge of language and text/genre conventions influenced their responses to texts. (Beach 1993:17).

Experiential Reader-Response Strategy is indicated by the readers' behaviour in responding a text. They usually engage in the text and connect the text with their experiences (Beach 1993:49). The experiences could be what the reader face in the real life or the previous reading they perform with had connection with text they were reading. Stanley Fish in Cordell \& Pennington, proposed the term affective stylistic to refer a state where the readers in responding a text focused on the process of reading (Cordell \& Pennington ,2012:296). Affective stylistic refers to a state where the readers first accept the meaning of the text as it, then concentrate on their reading responses while reading, and ultimately describe the reading experience by structuring their reading responses. (Cordel \& Peninngton, 2012:296).

Psychological Reader-Response Strategy assume that readers' responses are formed by their level of cognitive or intellectual development, cognitive abilities and processes, and subconscious forces (Beach, 1993:80). Readers in seeing text have their own interpretation, whether it is in line with common 
interpretation or in the contrary. Readers "re-symbolize" the text through their perceptions, opinions and beliefs. (Cordel \& Peninngton, 2012:298).

Social Reader-Response Strategy is a way to respond text by connecting text to a certain social values or roles. Readers adopt certain social roles in a group leader, teacher, robber, advocate, outsider; etc. that form certain ways of responding (Beach, 1993:108). In responding the text, the reader could place themselves to be member of social life, then gives a respond from the point of view the role he or she takes. The reader may relate some phenomenon from the text with the fact or event occur in a social life in a realty. Readers adjust and alter their theories to fit particular social situations. (Beach, 1993:107).

Cultural Reader-Response Strategy is indicated by readers' attempt to bring their personal background to the reading of a text. (Cordel \& Peninngton, 2012:303). One of the readers' background that affects their ways to respond text is religious or belief background. Beach in responding the structuralists and poststructuralists different opinions, states that Poststructuralists define the ways in which schools, businesses, organized religions, or governments limit the signified of the signifier to meanings consistent with their own institutional ideology (1993:126).

\section{RESEARCH METHOD}

In this study, the writer applies qualitative research. The data sources are library and literature data. Qualitative research is a way of learning about social reality. Qualitative approaches to research can be used across the disciplines to study a wide array of topics. In the social and behavioral sciences, these approaches to research are often used to explore, describe, or explain social phenomenon; unpack the meanings people ascribe to activities, situations, events, or artefacts; build a depth of understanding about some aspect of social life; build "thick descriptions" of people in naturalistic settings; explore new or under researched areas; or make micro-macro links. (Leavy 2014:2) 
The steps to conduct the research are as follows: 1) Defining something to investigate; 2) Collecting relevant data; 3) Analyzing and interpreting the results; and 4) Drawing conclusions based on the empirical findings. (Yin, 2011:49) The object of the study is the responses from amazon customers and the guest who drop responds to the Da Vinci Code novel in amazon.com. The responses which are taken are from the paperback version and it is limited to the responses which were dropped on June $10^{\text {th }} 2006$ until February $7^{\text {th }} 2015$.

The techniques of data collection are as follows; (1) Printing the responses about the Da Vinci Code novel paperback version from amazon.com, in form of PDF format, (2) Classifying the data according to the type of the responses by using Microsoft Office Excel's table. The classifying is sorted by the strategy that is used, (3) reading the data that have been classified repeatedly, (4) taking notes of important parts of data. (5) Selecting particular parts considered important and relevant for analysis. (6) Drawing conclusion and formulate the suggestions.

\section{FINDING AND DISCUSSION}

After analyzing the application of reader response strategies on Dan Brown's the Da Vinci Code the writer finds strategies used by the readers to respond the novel as follows;

\section{Textual reader-response strategies}

This strategy has two main indicators that can be used to identify whether a response belong to the category or not. These two main indicators are describing and judging.

The writer, then made further research about what the respondent describe and judge. It was found that the respondents in describing, they talked about character, plot, setting, style and theme. While judging, they judge the content of the novel, storyline, the author and the writing. 
There are 298 responses or $67.27 \%$ responses describing and judging about the novel, or in the other words using textual reader-response strategy. 24 or $5.42 \%$ describe about the character, 16 or $3.61 \%$ describe the plot, 4 responses or $0.90 \%$ respond to setting, 26 or $5.87 \%$ respond to the style and 42 or $9.48 \%$ respond to the theme of the novel. Overall there are 112 responses or $25.28 \%$ respond the novel by describing. The other main indicator that the writer used to classify the responses is judging. There are 117 responses or $26.41 \%$ respond to the content of the novel, 12 or $2.71 \%$ respond to the storyline, 53 or $11.96 \%$ respond by judging the author and 4 or $0.90 \%$ respond to the writing. Overall there are 186 responses or $41.99 \%$ respond to the novel by judging. The summary of the responses above is presented in the table below.

Table 1. Frequency and Percentage of Responses by using Textual Reader-response Strategy

\begin{tabular}{|c|c|c|c|c|}
\hline \multicolumn{2}{|c|}{ Textual Reader-response Strategy } & Freq. & Percent. & Total percent. \\
\hline \multirow[t]{5}{*}{ Describing } & Character & 24 & $5.42 \%$ & \multirow[t]{5}{*}{$25.28 \%$} \\
\hline & Plot & 16 & $3.61 \%$ & \\
\hline & Setting & 4 & $0.90 \%$ & \\
\hline & Style & 26 & $5.87 \%$ & \\
\hline & Theme & 42 & $9.48 \%$ & \\
\hline \multirow[t]{4}{*}{ Judging } & Content & 117 & $26.41 \%$ & \multirow[t]{4}{*}{$41.99 \%$} \\
\hline & Storyline & 12 & $2.71 \%$ & \\
\hline & The author & 53 & $11.96 \%$ & \\
\hline & Writing & 4 & $0.90 \%$ & \\
\hline
\end{tabular}

The most used strategy is Textual reader-response strategy. Many readers applied this strategy to express their responses. The most responded of textual aspect of the novel, is the content of the novel, in other word many reader focus to leave responses or comments to describe or judge the content of the novel, some of them focus on intrinsic element of the novel, character, plot, 
setting etc. Others focus to judge the author. Dan Brown seems success in shaping various responses from the reader about him.

The issues which are raised dealing with character are the existence of Sophie as descendant of Jesus. Of course, this "fact" of the story upsets the readers who could be Cristian or Catholic. This term come to a contradiction, "is this fact or fiction?"

\section{Psychological reader-response strategies}

This strategy has two indicators that can be used to identify whether a response belong to the category or not. These two main indicators are explaining what the characters do and interpreting their opinion about story or part of the story in the novel.

There are $7 \%$ or 31 responses that can be categorized as response using the psychological reader-response strategy. 2 responses or $0.45 \%$ talked about character's action, and 29 or $6.55 \%$ responses talked about respondents' opinion about certain part of the story by interpreting it in order to express their ideas. The summary of the responses above is presented in the table below.

Table 2. Frequency and Percentage of Responses by using Psychological Reader-response Strategy

\begin{tabular}{|l|c|c|}
\hline Psychological Reader-response Strategy & Freq. & Percent. \\
\hline Explaining Character's Action & 2 & $0.45 \%$ \\
\hline Interpreting & 29 & $6.55 \%$ \\
\hline
\end{tabular}

The readers quote some scenes, statements or something else, then interpret them according to their own opinion. For example, a reader give a response on the debatable topic, whether the novel is either fact or fiction. A reader have an opinion whether the historical documents are true but it is totally fiction after all. Another reader has an idea, that the blending of fact and fiction is just a way to make the story interesting etc. 
Responses which are expressed by using this kind of strategy, almost all focus on history accuracy and the truth "fact" in the novel. Some readers argue that, the lack of history's accuracy become the main problem of the novel and it leaves the readers to argue about this according to their own opinion. And again the main problem remain debated by the reader by interpreting what the novel offer is the fact of Priory of Sion, Opus Dei and Mary Magdalene.

\section{Experiential reader-response strategies}

This strategy has two main indicators that can be used to identify whether a response belong to the category or not. These two main indicators are connecting and engaging.

The writer then made further research about to what the respondent connect the story or part of it and how the respondent engage themselves into the story. The respondents in connecting the story or part of it, since it is to be classified to experiential, the writer picks the experience and the other story as additional indicator, which are used by the respondent to relate to main story or issue (connecting). There are 63 responses or $14.22 \%$ that can be classified to be responses that used experiential reader-response strategy. 9 responses or $2.03 \%$ that connect the story to respondent's experience and 40 responses or $9.03 \%$ which talk connecting the story to other story.

In engaging response, respondents are engaging with a story when they are articulating their personal emotional reaction or level of involvement with the story. There are 3 responses or $0.68 \%$ indicate the respondents used their feeling to involve in the story, 5 responses or $1.13 \%$ show the respondents used their imagination to involve in the story and 6 responses or $1.35 \%$ show the respondent used their thought to involve in the story. The summary of the responses above is presented in the table below. 
Table 3. Frequency and Percentage of Responses by using experiential Reader-response Strategy

\begin{tabular}{|l|l|c|c|c|}
\hline \multicolumn{2}{|l|}{ Experiential Reader-response Strategy } & Freq. & Percent. & Total percent. \\
\hline \multirow{2}{*}{ Connecting } & Experience & 9 & $2.03 \%$ & \multirow{2}{*}{$11.06 \%$} \\
\cline { 2 - 4 } & Other Story & 40 & $9.03 \%$ & \\
\hline \multirow{3}{*}{ Engaging } & Feeling & 3 & $0.68 \%$ & \multirow{2}{*}{$3.16 \%$} \\
\cline { 2 - 4 } & Imagination & 5 & $1.13 \%$ & \\
\cline { 2 - 4 } & Thought & 6 & $1.35 \%$ & \\
\hline
\end{tabular}

Mostly, the readers connect the novel with other story; in this case readers connect the Da Vinci Code is connected with other Brown's novel, either Angels and Demons or Digital Fortress. In the Angels and Demons, the protagonist is the same with what is presented in the Da Vinci Code, because of it the two works, maybe, are connected to each other. Another way connecting the Da Vinci Code with other works is by comparing it with the work that contain objections to the content of the novel, one of them is The Da Vinci Hoax by Olsen and Miesel. The readers outline some "wrong" statements in the novel and comparing or correcting the statement to other statements in the other books and commented in it by saying "the novel is wrong."

The issues that are raised by the readers dealing with the experiences of the reader are the novel affection to the readers to do some researches after reading it. The readers doing so to ensure themselves, that the setting or characters, such as Priory of Sion or Opus Dei are real. Some readers also connect the setting of place with their experiences visiting Paris, especially the Louvre museum.

\section{Cultural reader-response strategies}

This strategy has an indicator that can be used to identify whether a response belong to the category or not. This indicator is connecting the story or part of it to a religion value. There are $6.77 \%$ or 30 responses that can be 
categorized as responses using the cultural reader-response strategy. Those responses are constructed by connecting the story with Catholic value.

The readers connect some scenes of the novel with the doctrine in Catholic and bible. The main theme that make the novel become a controversy in the church is that Jesus got married and have children and off course it will be denied by most Catholic or Christian, by explaining what the bible say about it, how the ancient manuscript denied it, etc.

If we outline the Catholic or Christian values and bible say about things contradict the Da Vinci Code main themes, we will get major issues, as the writer stated before, which be debatable problem debated among the readers. Some readers accused Brown as a liar and through the Da Vinci Code, he wanted to undermine a certain religion. However, there are also some readers who agree with what presented in the novel. They say that people have been destroyed by the Catholic Church and the novel had shown people how the Church really is, another say that the novel is kind of alternative way how to see the truth of the religion and another one say that the novel had broken down the bible lies.

The base belief of Christian and Catholic is Jesus is god and he had no wife and children. Then if this belief is "attacked" by such literary work the followers of the religion will, of course, counter that attack. But there are also the people of these religions who are hesitant about what the bible say, then they find the novel, they feel the novel gives them some "true" facts, and they reveal it to the public. This will lead to a debate and the debate itself will make the novel gets its popularity. Some readers who are against with the main theme of the novel, give proofs that what presented in the novel is wrong by citing some verses from the bible, other readers who agree with the novel say that the bible also contains some wrong statements, and it seems this is a such condition expected by the author to shape the cult of his work. 


\section{Social reader-response strategies}

This strategy have an indicator that can be used to identify whether a response belong to the category or not. This indicator is connecting the story or part of it to a social life value or something related to it. There are $4.74 \%$ or 21 responses that can be categorized as response using the social reader-response strategy. Those responses are constructed by connecting the story with certain social life value or something related to it.

Social strategy is also used by some readers, by connecting the existence of Opus Dei and Priory of Sion. Once again, the readers come to a conclusion that, the two organizations are true and exist, but it cannot make the novel be a non-fiction work, it is still fiction. Others deny the existence of Priory of Sion, by saying it is created by Pierre Plantard, another argues it is just a story written by Henry Lincoln.

The long discussion about the existence of Priory of Sion, came to two main sources proposed by Lincoln and Plantard. Henry Lincoln, who the author of the Holy Blood, Holy Grail, proposed the term Priory of Sion, after doing some research in a small village Rennes le Chateau, He suggested that Sauniere, the priest of Rennes Le Chateau, had acquired his mysterious wealth through his association with a shadowy organization, and the clues were in those parchments. Lincoln claimed that his researches have thrown up several times the name Priory of Sion

\section{CONCLUSION}

The writer concludes that readers who drop responses about the Da Vinci Code novel, paperback version in amazon.com used various reader response strategies. Most of them in responding the novel use textual reader-response strategies, by judging the author, describe some intrinsic element of the novel etc. Some of them used more than one strategy in their responses, for example a 
reader responds about the author, he judges the author as so and so, in other paragraph he also responses about the contradictory in the novel dealing with the concept of divinity in Catholic. It means that he has used two kind textual and cultural reader response strategies.

Some of the readers who use experiential reader response strategies and they who use cultural reader response strategies have similarity in giving responses. Both of them when deny the concept of divinity in the novel relate or connect the concept either with the Bible or with Olsen's The Da Vinci Hoax: Exposing the Errors in the Da Vinci Code. This debatable idea perhaps is a central problem that make the readers think deeper about the matter and searching others nonfiction reference to compare it with the novel.

Many readers, whether they agree or not with the content, especially with the concept of divinity in the novel, have approved that the novel is a page turner, fast paced and thrilling, it means that most of the readers have the same opinion dealing with the textual of the novel.

From analysis of the application of the strategies above, it can be seen clearly that, a debatable problem about fact or fiction dealing with what the novel presented become the most dominant issue raised by the readers in responding Dan Brown's the Da Vinci Code.

\section{ACKNOWLEDGMENT}

Praise be to Allah for His blessing, so that the researcher is finally able to finish this article, and the writer's special thanks are extended to his parents, his wife, his children and his friends in STIKES An NurPurwodadi.

\section{REFERENCES}

Abrams, M. H. (1999). A Glossary Of Literary Terms. Boston: Heinle\&Heinle. Baigent, M., Leigh, R., \& Lincoln, H. (1982). The Holy Blood And The Holy 
Grail. London: J. Cape.

Baldick, Chris.(2001).The Concise Oxford Dictionary of Literary Terms.NewYork:Oxford University Press

Beach, R. (1993). A Teacher's Introduction To Reader-Response Theories. Urbana, Ill: National Council of Teachers of English.

Berg, Bruce. L.(2001).Qualitative Research Methods For The Social Sciences.4th Ed.Toronto.Allyn\& Bacon

Brown, D. (2003). The Da Vinci Code: A novel. New York: Doubleday.

Disher, G. (2001). Writing Fiction: An Introduction To The Craft. Crows Nest, N.S.W: Allen \&Unwin.

Ehrman,Brat.D.(2005).Misquoting Jesus: The Story Behind Who Changed the Bible and Why.NewYork:HarperCollins Publishers Inc

Fajri, Muhammad.(2009).The Application of Connecting Strategy In Appreciating Brown's Film The Da Vinci Code By The Fourth Semester Students Of English Study Program Faculty Of Teacher Training And Eduction University Of PGRI Palembang.Thesis, University Of PGRI Palembang

Ferris, S. (2005). The Key To The Da Vinci Code. Chichester: Crombie Jardine.

Gorfkle, Kenneth Max.(2008).Allegory Or Parody? Interpretation Of The Libro De Buen Amor's "TrobaCazurra" Lyric And Reader-Response And Reception Theory.Thesis, the University of North Carolina

Hammond, Heidi Kay.(2010).Graphic Novels And Multimodal Literacy: A Reader Response Study.Journal of Graphic Novels and Comics.1(2).doi: 10.1080/21504857.2010.526378

Iskhak (2015).The Application of Reader-response Theory in Enhancing Student Teachers' Affective and Linguistic Growth: A Classroom Action Research in EFL Teacher Education in Indonesia.Journal of the Malaysian English Language Teaching Association. XLIV(2), 43-55

Leavy, P. (2014). The Oxford Handbook Of Qualitative 
Research.NewYork:OxfordUniveristy Press

Piturro, Vincent .(2008).The Audience And The Film: A Reader-Response Analysis Of Italian Neorealism.Dissertation, University of Colorado

Shelton, Jeremiah Adam.(2009).A Comparative Reader-Response Analysis Between The Stranger And Crime And Punishment.Thesis, California State University

Yin, R. K. (2011). Qualitative Research From Start To Finish.New York : The Guilford Press 